\title{
SCIENTIFIC REPORTS

\section{OPEN Improving understanding of carbon stock characteristics of Eucalyptus and Acacia trees in southern China through litter layer and woody debris}

\begin{abstract}
Hui Zhang ${ }^{1}$, Yinhua Jiang ${ }^{2}$, Mingwei Song ${ }^{3 *}$, Jiajun $\mathrm{He}^{2 *}$ \& Dongsheng Guan ${ }^{4}$
Surveying the quality and quantity of carbon stock in litter layer and woody debris of Eucalyptus and Acacia plantations is critical in understanding their carbon pools. Here, the focus of the present study was on a number of Eucalyptus and Acacia plantations of different stand aged in the Pearl River Delta region of southern China. The plantation type proved to be a crucial driver of the carbon concentration in litter layer and woody debris, with Acacia exhibiting a superior ability to Eucalyptus to accumulate carbon with stand age in both these materials. The relative contribution of the litter layer and woody debris to the carbon stock of the ecosystem was also significantly higher under mature Acacia ( $8 \%$ and $7 \%$, respectively) than that under mature Eucalyptus ( $4 \%$ and $1 \%$, respectively). Most of the carbon stock within the litter layer was present in the leaf debris. The carbon stock in woody debris was mainly contained in the components within the $10-20 \mathrm{~cm}$ diameter class during the primary decay stage, represented as snags in middle-aged and mature Acacia, and as logs for mature Eucalyptus, respectively. The results indicate that both plantation type and stand age influence the characteristics of carbon stored in litter layer and woody debris significantly.
\end{abstract}

The litter layer and woody debris constitute important components of forest ecosystem, and are accumulated on the forest floor, serving as a source of organic matter and nutrients to the soil ${ }^{1-3}$. Assessment of the quality and quantity of the woody debris has led to the discovery that its quantity, type, diameter class and decay class are determined by stand structure, ecosystem function and forest management history ${ }^{1-4}$. The management of the forest ecosystem is increasingly viewed as a way of mitigating against the negative effects of climate change $e^{5,6}$. The stock of carbon (C) stored in litter layer and woody debris, along with its contribution to the ecosystem, is assumed to depend largely on the tree type and age $\mathrm{e}^{7-9}$. Generally, in natural/secondary forests, a substantial proportion of $\mathrm{C}$ stock is contained in litter layer and woody debris, e.g., in a secondary forest aged 75 years, they contain an estimated $20 \%$ of the total ecosystem accumulation of $\mathrm{C}$ stock ${ }^{10}$. In subtropical evergreen broad-leaved forests, the relatively low turnover rate of woody debris ( $<22$ year) led to a relatively slow release of $\mathrm{C}^{2}$, indicating that woody debris is an important component of long-term $\mathrm{C}$ pools in these areas. Most attempts to characterize the $\mathrm{C}$ stock in the woody debris of forests growing in subtropical climate zone have focused on natural/secondary evergreen broad-leaved forests ${ }^{2,8}$. However, the relationship of the quality and quantity of woody debris $\mathrm{C}$ stock with tree species and ages in subtropical plantations remain unclear. Currently, China contains the largest land mass of plantations in the world ( $\sim 69$ million ha in 2013$)^{11}$. An estimated $80 \%$ of the increase in the national $\mathrm{C}$ sink can be attributed to forest plantations, with those in southern China representing $65 \%$ of the national C $\operatorname{sink}^{12}$. Eucalyptus spp. and Acacia spp. are tree species native to the tropical zone. Owing to their rapid growth rate and ability to thrive on poor soil, both Eucalyptus (non- $\mathrm{N}_{2}$-fixing species) and Acacia ( $\mathrm{N}_{2}$-fixing species) have

\footnotetext{
${ }^{1}$ School of Chemistry and Environmental Engineering, Wuhan Institute of Technology, 430205, Wuhan, China. ${ }^{2}$ School of Management, Wuhan Institute of Technology, 430205, Wuhan, China. ${ }^{3}$ College of Resources and Environment, Huazhong Agricultural University, 430070, Wuhan, China. ${ }^{4}$ School of Environmental Science and Engineering, Sun Yat-sen University, 510275, Guangzhou, China. *email: songmw@mail.hzau.edu.cn; hjj1618@163.com
} 
been planted widely in the Pearl River Delta (PRD) region of southern China during a reforestation initiative of the provincial government of Guangdong, targeting areas where the soil had become badly degraded in the 1980s.

The relative effectiveness of these species to sequester $\mathrm{C}$ is in question. Certain studies have suggested that the size of the soil C pool does not respond to afforestation with Eucalyptus and Acacia trees ${ }^{13,14}$, while others have reported the contrary results, claiming that the $\mathrm{C}$ sequestration ability of Acacia is generally superior to that of Eucalyptus ${ }^{15}$. A thorough study on the quality and quantity of $\mathrm{C}$ stock in litter layer and woody debris is critical in understanding the role of the $\mathrm{C}$-sequestration capacity of $\mathrm{N}_{2}$-fixing and non- $\mathrm{N}_{2}$-fixing trees and their difference. However, insufficient data exist on the characteristic of the $\mathrm{C}$ source, including the $\mathrm{C}$ stock in the forest floor layer, for these two plantation types. Typically, Eucalyptus and Acacia plantations used for wood production are maintained for under ten years ${ }^{16,17}$. To the best of our knowledge, no extensive study has been performed to date on the long-term dynamic characteristics of the $\mathrm{C}$ stock in the litter layer and woody debris and the association with tissue type and stand ages for Eucalyptus and Acacia plantations in subtropical zone. The quantity of stored $\mathrm{C}$ is dependent on both the volume of the biomass and the relative $\mathrm{C}$ concentration therein. The $\mathrm{C}$ concentration in the litter layer and the woody debris is rarely measured directly; rather, there is a tendency to assume a value of $50 \%{ }^{18,19}$.

However, an increasing amount of evidence now indicates that this proportion depends on various parameters, including tree species, stand age, stand condition, local climate, decay stage/decay class and tissue type ${ }^{2,6,20-22}$. For example, certain studies have reported that the $\mathrm{C}$ concentration of litter and woody debris not only varies significantly by forests type ${ }^{20,23}$, but also that it is age-dependent in natural forests as well as plantations ${ }^{2,6}$. Given the wide range of $C$ concentration in the litter layer of subtropical forests $(40-58 \%)^{6,7,23,24}$, and in the woody debris in tropical and subtropical forests $\left(20-52 \%\right.$ and $45-61 \%$, respectively ${ }^{22,25}$, this value should be measured in order to improve the accuracy of $\mathrm{C}$ stock estimation. The present study therefore aimed to characterize the $\mathrm{C}$ pools stored in samples of the litter layer and woody debris of 21 Eucalyptus and Acacia plantations in the PRD region. Our specific objectives were to test the three hypotheses: firstly, that the $\mathrm{C}$ concentration of the litter layer and woody debris is dependent on either the species of tree being grown and/or the stand age; secondly, that forest type and stand age affect the $\mathrm{C}$ stock held in the woody debris of a specific diameter class and/or state of decay; and finally, that both forest type and stand age contribute to the capacity of a plantation to store $\mathrm{C}$ in the litter layer and/or the woody debris.

\section{Materials and methods}

Site description. The PRD region lies in Guangdong Province, China $\left(21^{\circ} 31^{\prime}-23^{\circ} 10^{\prime} \mathrm{N}, 112^{\circ} 45^{\prime}-113^{\circ} 50^{\prime} \mathrm{E}\right)$. Its climate is characterized by hot, humid summers and mild winters. A large proportion of the mean annual rainfall of $1,600 \mathrm{~mm}$ falls during the months of July and August. The mean annual temperature is approximately $21^{\circ} \mathrm{C}$, with daytime temperatures exceeding $30^{\circ} \mathrm{C}$ on around 120 days per year. In the present study, a set of 21 plantations was studied: ten were planted exclusively to Acacia and 11 exclusively to Eucalyptus.

The two types of rapidly growing trees species were planted in degraded red soil, on hilly sites in the neighborhood of the cities of Heshan, Zhuhai and Guangzhou. The monitoring period was November 2010 to January 2011. The stand age of the plantations was classified as either young ( $<6$ years), middle-aged ( $6-15$ years) or mature ( $>16$ years). The mortality rate of canopy in young Acacia plantations was $5.3 \pm 1.2 \%$, while there was no appreciable mortality in the young Eucalyptus plantations. The mortality rates in the middle-aged plantations were $11.9 \pm 5.0 \%$ for Acacia and $4.4 \pm 1.2 \%$ for Eucalyptus; in the mature plantations, the respective rates were $14.9 \pm 6.5 \%$ and $4.0 \pm 1.7 \%$. Further descriptive details of the sites are given by Zhang et al. ${ }^{26}$ and are reproduced in Table 1.

Sampling. Each plantation was sampled by a single $30 \mathrm{~m} \times 30 \mathrm{~m}$ square, in which the tree heights above $3 \mathrm{~m}$ were measured using a digital hypsometer, while their diameter at breast height (1.3 $\mathrm{m}$ above ground level) (hereafter $\mathrm{DBH}$ ) was obtained using a diameter tape. Allometric equations suggested by Ye et al. ${ }^{27}$ and Ren et al. ${ }^{28}$ were subsequently used to calculate the biomass of the arbor layer. The understory biomass was estimated by destructive sampling from the central $1 \mathrm{~m}^{2}$ of five $2 \mathrm{~m} \times 2 \mathrm{~m}$ plots, including all shrubs, ferns and grasses. The shrubs were separated into twigs, branches, leaves and roots, and the herbaceous species into above- and below-ground material. After obtaining fresh weights, a weighed sub-sample was oven-dried at $65^{\circ} \mathrm{C}$ until constant weight (dry weight), and the loss of weight was used to estimate tissue water content. The litter layer contribution was obtained from a set of five $1 \mathrm{~m} \times 1 \mathrm{~m}$ quadrats arranged along the diagonal of the $30 \mathrm{~m} \times 30 \mathrm{~m}$ square: it comprised leaf debris, fallen fruits, bark and fallen twigs ( $<10 \mathrm{~mm}$ diameter). The fresh weight of each component was measured on site and its dry weight was measured after oven-drying. Following the suggestions of Wei et al. ${ }^{29}$ and Tang and $\mathrm{Zhou}^{30}$, woody debris measurements were restricted to snags (standing dead trees), logs (fallen dead trees) of minimum end diameter $2.5 \mathrm{~cm}$ and minimum length $1 \mathrm{~m}$. The woody debris was organized into four diameter-based classes: $2.5-10 \mathrm{~cm}, 10-20 \mathrm{~cm}, 20-30 \mathrm{~cm}$ and $>30 \mathrm{~cm}$. The selected woody debris pieces were divided into five decay classes using a five-step wood decay classification: classes I and II reflect an early stage of decay, classes III and IV an intermediate stage, and class V an advanced stage. To determine wood density, we cut small pieces of wood from woody debris based on decay class and species. In total, we obtained approximately 25-30 fragments for each plot. Moisture contents were obtained by oven-drying, while their volume was inferred using a water displacement method.

Laboratory analysis. The quantity of $\mathrm{C}$ present in vegetable tissues was calculated by multiplying biomass by $\mathrm{C}$ concentration. Total ecosystem biomass was the sum of the dry weight stored in these four vegetable tissues, including the canopy, understory layers, litter layer and woody debris. Tissue $\mathrm{C}$ concentration was determined via digestion in acidified potassium dichromate (LY/T1237-1999, Forestry Standards of the People's Republic of China). A $0.0050-1.0000 \mathrm{~g}$ sample was digested in $5 \mathrm{~mL} 0.8000 \mathrm{M} \mathrm{K}_{2} \mathrm{Cr}_{2} \mathrm{O}_{7}$ plus $5 \mathrm{~mL} 18.4 \mathrm{M} \mathrm{H}_{2} \mathrm{SO}_{4}$, then 


\begin{tabular}{|c|c|c|c|c|c|c|c|}
\hline No. & Latitude & Longitude & $\begin{array}{l}\text { Constructive } \\
\text { Species }\end{array}$ & $\begin{array}{l}\text { Stand } \\
\text { age (a) }\end{array}$ & $\begin{array}{l}\text { Mean DBH } \\
(\mathrm{cm})\end{array}$ & $\begin{array}{l}\text { Mean tree } \\
\text { height }(\mathrm{m})\end{array}$ & $\begin{array}{l}\text { Stand density } \\
\left(\text { trees }^{\prime} \mathrm{hm}^{-2}\right)\end{array}$ \\
\hline 1 & N. $23^{\circ} 11^{\prime}$ & E. $113^{\circ} 22^{\prime}$ & E. citriodora & 18.0 & $17.8 \pm 13.1$ & $19.4 \pm 6.8$ & 933.3 \\
\hline 2 & $\mathrm{~N} .23^{\circ} 11^{\prime}$ & E. $113^{\circ} 22^{\prime}$ & E. urophylla & 4.0 & $8.7 \pm 4.0$ & \begin{tabular}{|l}
$12.0 \pm 3.9$ \\
\end{tabular} & 2777.8 \\
\hline 3 & $\mathrm{~N} .23^{\circ} 18^{\prime}$ & E. $113^{\circ} 23^{\prime}$ & E. urophylla & 16.0 & $15.2 \pm 15.3$ & $16.9 \pm 4.6$ & 1344.4 \\
\hline 4 & N. $22^{\circ} 57^{\prime}$ & E. $113^{\circ} 18^{\prime}$ & E. urophylla & 8.0 & $12.3 \pm 5.9$ & $14.9 \pm 3.4$ & 1600.0 \\
\hline 5 & N. $23^{\circ} 18^{\prime}$ & E. $113^{\circ} 25^{\prime}$ & E. urophylla & 11.0 & $13.6 \pm 4.2$ & $14.8 \pm 3.9$ & 1744.4 \\
\hline 6 & $\mathrm{~N} .22^{\circ} 21^{\prime}$ & E. $113^{\circ} 34^{\prime}$ & E. urophylla & 1.5 & $6.1 \pm 3.2$ & $7.1 \pm 2.6$ & 2866.7 \\
\hline 7 & N. $23^{\circ} 11^{\prime}$ & E. $113^{\circ} 23^{\prime}$ & E. urophylla & 2.5 & $7.8 \pm 4.0$ & $10.0 \pm 3.9$ & 2622.2 \\
\hline 8 & N. $22^{\circ} 21^{\prime}$ & E. $113^{\circ} 34^{\prime}$ & E. urophylla & 6.0 & $11.3 \pm 4.9$ & $14.7 \pm 3.0$ & 1653.3 \\
\hline 9 & N. $22^{\circ} 40^{\prime}$ & E. $112^{\circ} 54^{\prime}$ & E. urophylla & 1.0 & $5.9 \pm 2.5$ & $5.1 \pm 2.9$ & 2777.8 \\
\hline 10 & N. $22^{\circ} 40^{\prime}$ & E. $113^{\circ} 54^{\prime}$ & E. urophylla & 25.0 & $12.2 \pm 4.7$ & $20.3 \pm 3.1$ & 1822.2 \\
\hline 11 & N. $22^{\circ} 40^{\prime}$ & E. $112^{\circ} 54^{\prime}$ & E. urophylla & 10.0 & $12.3 \pm 4.9$ & $14.2 \pm 3.5$ & 1877.8 \\
\hline 12 & N. $23^{\circ} 40^{\prime}$ & E. $113^{\circ} 25^{\prime}$ & A. mangium & 12.0 & $12.6 \pm 8.4$ & $9.7 \pm 4.2$ & 1111.1 \\
\hline 13 & N. $23^{\circ} 18^{\prime}$ & E. $113^{\circ} 25^{\prime}$ & A. mangium & 17.0 & $17.8 \pm 8.9$ & $13.6 \pm 3.9$ & 816.7 \\
\hline 14 & N. $23^{\circ} 18^{\prime}$ & E. $113^{\circ} 23^{\prime}$ & A. mangium & 5.5 & $9.1 \pm 7.8$ & $7.1 \pm 2.0$ & 1544.4 \\
\hline 15 & 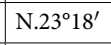 & E. $113^{\circ} 23^{\prime}$ & A. mangium & 4.5 & $8.9 \pm 4.4$ & $7.0 \pm 2.4$ & 1555.6 \\
\hline 16 & N. $22^{\circ} 21^{\prime}$ & E. $113^{\circ} 34^{\prime}$ & A. auriculaeformis & 15.0 & $14.7 \pm 7.8$ & $11.9 \pm 4.6$ & 1200.0 \\
\hline 17 & N. $22^{\circ} 21^{\prime}$ & E. $113^{\circ} 34^{\prime}$ & A. auriculaeformis & 13.0 & $12.2 \pm 5.0$ & $9.5 \pm 3.7$ & 1222.2 \\
\hline 18 & N. $22^{\circ} 20^{\prime}$ & E. $113^{\circ} 34^{\prime}$ & A. auriculaeformis & 8.0 & $10.2 \pm 4.7$ & $8.2 \pm 2.7$ & 1444.4 \\
\hline 19 & N. $22^{\circ} 40^{\prime}$ & E. $112^{\circ} 53^{\prime}$ & A. mangium & 26.0 & $20.7 \pm 10.2$ & $16.1 \pm 4.4$ & 833.3 \\
\hline 20 & N. $22^{\circ} 40^{\prime}$ & E. $112^{\circ} 54^{\prime}$ & A. mangium & 5.0 & $8.1 \pm 2.8$ & $7.1 \pm 1.4$ & 1522.2 \\
\hline 21 & N. $22^{\circ} 41^{\prime}$ & E. $112^{\circ} 53^{\prime}$ & A. mangium & 18.0 & $17.7 \pm 6.2$ & $15.0 \pm 2.2$ & 840.0 \\
\hline
\end{tabular}

Table 1. The basic characteristics in the experimental forest stands. Note: Values given as mean \pm SD.

heated to $170-180^{\circ} \mathrm{C}$ for $5 \mathrm{~min}$. The resulting solution was titrated against $0.2 \mathrm{M} \mathrm{FeSO}_{4} .7 \mathrm{H}_{2} \mathrm{O}$. In the litter layer and woody debris, the overall $\mathrm{C}$ stock in the original sample was obtained by multiplying the $\mathrm{C}$ concentration by the sample weight. The calculated biomass in the canopy and understorey layers were converted into fixed $\mathrm{C}$ by multiplying by $0.5^{31}$.

Statistical analysis. The mean C concentration and C stock, and respective associated standard deviation (SD) of the litter layer and the woody debris from young, middle-aged and mature Eucalyptus and Acacia plantations were calculated. A one-way analysis of variance (ANOVA) was used to test for any effect of forest type and/ or stand age on either the proportion or quantity of $\mathrm{C}$ stored in the litter layer and woody debris, also including respective various components, woody debris at different diameter class and decay classes. A Tukey's HSD test was used for comparison of means. All calculations and statistical analyses were carried out by Microsoft Excel 2016 and IBM SPSS (Version 22.0, SPSS Inc., USA).

Results

$\mathrm{C}$ concentration of litter layer and woody debris. There was a significant effect of forest type on the $\mathrm{C}$ concentration of both the litter layer and the woody debris, independent of stand age. In the Eucalyptus plantations, the mean C concentration was $44.5 \%$ (litter layer) and $45.8 \%$ (woody debris), while in the Acacia plantations, the equivalents were $48.3 \%$ and $48.9 \%$, respectively (Table 2 ). Within the litter layer, the $\mathrm{C}$ concentration of the leaf and branch material was significantly $(P<0.01)$ higher in the Acacia material (47.6-49.3\% \& 46.4-49.6\%) compared with the Eucalyptus leaf (44.2-47.3\%) and branch (42.8-44.2\%) materials. Regarding the woody debris, the $\mathrm{C}$ concentration of snags and logs was significantly $(P<0.05)$ higher in the Acacia $(47.4-51.0 \%$ \& 47.6-48.0\%, respectively) than in the Eucalyptus (46.5-47.1\% \& 45.7-44.8\%, respectively) plantations.

Carbon stock of the litter layer and the woody debris. Litter layer. The C stock of the litter layer, and the leaf and branch material contained within it increased substantially as stand age (Tables 3 and 4). Leaf debris and fallen branches dominated the C stock of the litter layer (87.3\% in Eucalyptus plantations and 95.7\% in Acacia plantations). The leaf material had the largest contribution to the $\mathrm{C}$ stock of this layer (73\% under Eucalyptus and 53\% under Acacia), which differed significantly $(P<0.01)$ between the two forest types: it was higher in the Acacia plantations than in the Eucalyptus ones.

Woody debris. The $\mathrm{C}$ stock of woody debris was significantly $(P<0.01)$ higher in Acacia than that in Eucalyptus plantations (Table 3 ). The $\mathrm{C}$ stored in woody debris was strongly related to stand age, as was the individual contribution of snags and logs. The largest part of the $\mathrm{C}$ stock of woody debris was contained in the snags, especially in the middle-aged and mature plantations (Table 3). Material of diameter $2.5-10 \mathrm{~cm}$ contributed the most to the $\mathrm{C}$ stock, especially in young Acacia plantations $\left(0.26 \mathrm{t} \cdot \mathrm{ha}^{-1}\right)$, which harbored about $60 \%$ of the total C stock in woody debris, mainly as logs (mean $75 \%$ ) (Table 4). Material of diameter 10-20 cm contributed most strongly to the $\mathrm{C}$ stored in woody debris in the middle-aged and mature plantations, particularly for middle-aged Eucalyptus (54\%) and Acacia plantations (46\%). The quantity of C stored in the component was, respectively, 0.61 and 0.17 


\begin{tabular}{|c|c|c|c|c|c|c|c|c|c|}
\hline Type & Period & Leaf & Brach & Bark & Fruit & Litter layer & Snags & $\operatorname{logs}$ & woody debris \\
\hline \multirow{3}{*}{ Eucalyptus } & Young & $46.13 \pm 0.89$ & $44.22 \pm 3.86$ & $41.45 \pm 1.24$ & $42.20 \pm 4.06$ & $45.03 \pm 1.54$ & - & - & - \\
\hline & Middle-aged & $44.18 \pm 1.82$ & $42.91 \pm 2.00$ & $39.91 \pm 2.09$ & $43.31 \pm 2.38$ & $43.26 \pm 1.78$ & $46.54 \pm 2.92$ & $45.72 \pm 1.68$ & $46.02 \pm 2.23$ \\
\hline & Mature & $47.29 \pm 3.00$ & $42.82 \pm 1.61$ & $43.05 \pm 2.22$ & $40.59 \pm 0.69$ & $45.27 \pm 1.86$ & $47.11 \pm 1.10$ & $44.80 \pm 0.83$ & $45.48 \pm 1.07$ \\
\hline \multirow{3}{*}{ Acacia } & Young & $47.58 \pm 0.91$ & $46.36 \pm 1.38$ & $43.31 \pm 0.56$ & $44.11 \pm 1.22$ & $47.25 \pm 0.56$ & $47.40 \pm 1.92$ & $47.55 \pm 1.30$ & $47.52 \pm 1.37$ \\
\hline & Middle-aged & $49.33 \pm 3.30$ & $49.60 \pm 2.58$ & $42.79 \pm 1.71$ & $45.32 \pm 1.50$ & $49.09 \pm 2.67$ & $50.25 \pm 2.13$ & $46.87 \pm 1.83$ & $49.30 \pm 1.58$ \\
\hline & Mature & $49.21 \pm 2.28$ & $46.91 \pm 4.04$ & $42.36 \pm 0.87$ & $43.44 \pm 2.84$ & $48.60 \pm 2.61$ & $51.03 \pm 1.56$ & $47.95 \pm 1.20$ & $49.96 \pm 0.84$ \\
\hline \multicolumn{2}{|l|}{ Forest types } & ** & $* *$ & ns & $*$ & $* *$ & $*$ & $*$ & $* *$ \\
\hline
\end{tabular}

Table 2. The $\mathrm{C}$ concentration in the various component of litter layer and woody debris for Acacia and Eucalyptus plantations (\%). Note: - means no statistic data, ns denotes not significant, while * and ** represent significant differences at $P<0.05$ level and extremely significant difference at $P<0.01$ level between the Eucalyptus and Acacia plantations, respectively, same as blow.

\begin{tabular}{|c|c|c|c|c|c|c|c|c|c|c|}
\hline Type & Period & Leaf & Brach & Bark & Fruit & Litter layer & Snags & $\operatorname{logs}$ & WD & $\begin{array}{l}\text { C stock of } \\
\text { ecosystem }\end{array}$ \\
\hline \multirow{3}{*}{ Eucalyptus } & Young & $0.49 \pm 0.14 \mathrm{Aa}$ & $0.29 \pm 0.26 \mathrm{a}$ & $0.05 \pm 0.04 \mathrm{a}$ & $0.08 \pm 0.07 \mathrm{a}$ & $0.91 \pm 0.40 \mathrm{~A}$ & - & - & - & $29.75 \pm 17.42 \mathrm{a}$ \\
\hline & \begin{tabular}{|l|} 
Middle-aged \\
\end{tabular} & $1.37 \pm 0.43 \mathrm{a}$ & $1.26 \pm 0.75 \mathrm{~b}$ & $0.22 \pm 0.11 \mathrm{ab}$ & $0.12 \pm 0.08 \mathrm{a}$ & $2.97 \pm 0.66 \mathrm{Ba}$ & $0.40 \pm 0.20$ & $0.18 \pm 0.14$ & $0.58 \pm 0.23$ & $75.67 \pm 12.44 \mathrm{~b}$ \\
\hline & Mature & $2.73 \pm 1.02 \mathrm{Bb}$ & $1.07 \pm 0.20 \mathrm{ab}$ & $0.39 \pm 0.32 \mathrm{~b}$ & $0.16 \pm 0.14 \mathrm{a}$ & $4.34 \pm 0.63 \mathrm{Bb}$ & $0.46 \pm 0.36$ & $0.75 \pm 0.06$ & $1.21 \pm 0.30$ & $103.16 \pm 3.69 \mathrm{c}$ \\
\hline \multirow{3}{*}{ Acacia } & Young & $1.55 \pm 0.09 \mathrm{Aa}$ & $0.28 \pm 0.06 \mathrm{Aa}$ & $0.05 \pm 0.01 \mathrm{a}$ & $0.02 \pm 0.02 \mathrm{a}$ & $1.91 \pm 0.17 \mathrm{~A}$ & $0.10 \pm 0.05 \mathrm{~A}$ & $0.33 \pm 0.10 \mathrm{a}$ & $0.43 \pm 0.13 \mathrm{~A}$ & $43.84 \pm 2.70 \mathrm{a}$ \\
\hline & Middle-aged & $3.42 \pm 0.78 \mathrm{Ab}$ & $2.04 \pm 0.48 \mathrm{Bb}$ & $0.15 \pm 0.09 \mathrm{ab}$ & $0.11 \pm 0.05 \mathrm{~b}$ & $5.73 \pm 1.12 \mathrm{Ba}$ & $2.76 \pm 1.04 \mathrm{Ba}$ & $1.80 \pm 1.33 \mathrm{ab}$ & $4.56 \pm 1.11 \mathrm{~B}$ & $70.53 \pm 13.02 b$ \\
\hline & Mature & $5.83 \pm 1.21 \mathrm{~B}$ & $1.43 \pm 0.68 \mathrm{Ab}$ & $0.22 \pm 0.06 \mathrm{~b}$ & $0.09 \pm 0.07 \mathrm{ab}$ & $7.57 \pm 0.95 \mathrm{Bb}$ & $3.94 \pm 1.01 \mathrm{Ba}$ & $2.74 \pm 1.30 \mathrm{~b}$ & $6.68 \pm 0.38 \mathrm{C}$ & $94.47 \pm 11.95 \mathrm{c}$ \\
\hline \multicolumn{2}{|l|}{ Forest types } & ** & ns & ns & ns & $*$ & ** & ** & ** & ns \\
\hline
\end{tabular}

Table 3. The $\mathrm{C}$ stored in the various component of litter layer and woody debris of Eucalyptus and Acacia plantations $\left(\mathrm{t} \cdot \mathrm{ha}^{-1}\right)$. Note: Values are shown as mean $\pm \mathrm{SD}$; different lower case $(P<0.05)$ and upper case $(P<0.01)$ letters within a column indicate a significant difference between the various ages of a given forest type; for instance, for $\mathrm{C}$ stored in leaf in Acacia plantations, the only significant difference $(P<0.05)$ was presented between young plantations and middle-aged plantations, while an extremely difference $(P<0.01)$ was observed between young plantations and mature plantations; ns: not significant, *significant difference $(P<0.05)$, **extremely significant difference $(P<0.01)$ between the Eucalyptus and Acacia plantations. The $\mathrm{C}$ stock of the ecosystem was obtained by multiplying the mass of each component by its $\mathrm{C}$ concentration. Thus, the ecosystem's $\mathrm{C}$ stock represents the sum of the $\mathrm{C}$ stock of the canopy layer, the understory layer, the litter layer and the woody debris.

\begin{tabular}{|c|c|c|c|c|c|c|c|c|c|c|c|c|c|}
\hline \multirow[b]{2}{*}{ Type } & \multirow[b]{2}{*}{ Period } & \multicolumn{3}{|c|}{$2.5 \sim 10 \mathrm{~cm}$} & \multicolumn{3}{|c|}{$10 \sim 20 \mathrm{~cm}$} & \multicolumn{3}{|c|}{$20 \sim 30 \mathrm{~cm}$} & \multicolumn{3}{|l|}{$>30 \mathrm{~cm}$} \\
\hline & & Snags & Logs & Total & Snags & Logs & Total & Snags & Logs & Total & Snags & Logs & Total \\
\hline \multirow{3}{*}{ Eucalyptus } & Young & $0 \mathrm{a}$ & $0 \mathrm{Aa}$ & $0 \mathrm{Aa}$ & 0a & $0 \mathrm{Aa}$ & $0 \mathrm{~A}$ & $0 \mathrm{a}$ & $0 \mathrm{Aa}$ & 0Aa & $0 \mathrm{a}$ & $0 \mathrm{a}$ & $0 \mathrm{a}$ \\
\hline & $\begin{array}{l}\text { Middle- } \\
\text { aged }\end{array}$ & $\begin{array}{l}0.117 \pm \\
0.11 \mathrm{~b}\end{array}$ & $\begin{array}{l}0.050 \pm \\
0.11 \mathrm{Bb}\end{array}$ & $\begin{array}{l}0.167 \pm \\
0.15 \mathrm{ABb}\end{array}$ & $\begin{array}{l}0.199 \pm \\
0.11 \mathrm{~b}\end{array}$ & $\begin{array}{l}0.116 \pm \\
0.09 \mathrm{Ab}\end{array}$ & $\begin{array}{l}0.314 \pm \\
0.12 \mathrm{Ba}\end{array}$ & $\begin{array}{l}0.085 \pm \\
0.09 \mathrm{a}\end{array}$ & $\begin{array}{l}0.014 \pm \\
0.01 \mathrm{Aa}\end{array}$ & $\begin{array}{l}0.098 \pm \\
0.09 \mathrm{ABa}\end{array}$ & $0.00 \pm 0.00 \mathrm{a}$ & $0.00 \pm 0.00 \mathrm{a}$ & $0.00 \pm 0.00 \mathrm{a}$ \\
\hline & Mature & $\begin{array}{l}0.051 \pm \\
0.01 \mathrm{ab}\end{array}$ & $\begin{array}{l}0.158 \pm \\
0.05 \mathrm{Bc}\end{array}$ & $\begin{array}{l}0.210 \pm \\
0.03 \mathrm{Bb}\end{array}$ & $\begin{array}{l}0.202 \pm \\
0.13 \mathrm{~b}\end{array}$ & $\begin{array}{l}0.405 \pm \\
0.07 \mathrm{Bc} \\
\end{array}$ & $\begin{array}{l}0.606 \pm \\
0.13 \mathrm{Bb}\end{array}$ & $\begin{array}{l}0.157 \pm \\
0.17 \mathrm{a} \\
\end{array}$ & $\begin{array}{l}0.124 \pm \\
0.08 \mathrm{Bb}\end{array}$ & $\begin{array}{l}0.280 \pm \\
0.12 \mathrm{Bb}\end{array}$ & $0.047 \pm 0.05 b$ & $0.064 \pm 0.06 \mathrm{~b}$ & $0.111 \pm 0.10 \mathrm{~b}$ \\
\hline \multirow{3}{*}{ Acacia } & Young & \begin{tabular}{|l|}
$0.044 \pm$ \\
$0.04 \mathrm{a}$ \\
\end{tabular} & $\begin{array}{l}0.213 \pm \\
0.12 \mathrm{a} \\
\end{array}$ & $\begin{array}{l}0.256 \pm \\
0.15 a\end{array}$ & $\begin{array}{l}0.056 \pm \\
0.03 \mathrm{a} \\
\end{array}$ & $\begin{array}{l}0.117 \pm \\
0.04 \mathrm{a} \\
\end{array}$ & $\begin{array}{l}0.174 \pm \\
0.07 \mathrm{Aa}\end{array}$ & 0a & 0a & OAa & $0 \mathrm{a}$ & $0 \mathrm{a}$ & $0 \mathrm{a}$ \\
\hline & $\begin{array}{l}\text { Middle- } \\
\text { aged }\end{array}$ & $\begin{array}{l}0.210 \pm \\
0.15 \mathrm{a}\end{array}$ & $\begin{array}{l}1.232 \pm \\
1.44 \mathrm{a}\end{array}$ & $\begin{array}{l}1.442 \pm \\
1.35 \mathrm{a}\end{array}$ & $\begin{array}{l}1.183 \pm \\
0.87 \mathrm{ab}\end{array}$ & $\begin{array}{l}0.334 \pm \\
0.15 a\end{array}$ & $\begin{array}{l}1.518 \pm \\
0.73 \mathrm{ab}\end{array}$ & $\begin{array}{l}0.813 \pm \\
0.99 \mathrm{ab}\end{array}$ & $\begin{array}{l}0.220 \pm \\
0.39 \mathrm{a}\end{array}$ & $\begin{array}{l}1.033 \pm \\
0.96 \mathrm{ab}\end{array}$ & $0.556 \pm 0.69 \mathrm{a}$ & $0.012 \pm 0.02 \mathrm{a}$ & $0.568 \pm 0.69 a$ \\
\hline & Mature & $\begin{array}{l}0.125 \pm \\
0.06 \mathrm{a}\end{array}$ & $\begin{array}{l}0.941 \pm \\
0.43 a\end{array}$ & $\begin{array}{l}1.067 \pm \\
0.45 \mathrm{a}\end{array}$ & $\begin{array}{l}1.994 \pm \\
1.04 \mathrm{~b}\end{array}$ & $\begin{array}{l}1.069 \pm \\
1.46 \mathrm{a}\end{array}$ & $\begin{array}{l}3.063 \pm \\
1.52 \mathrm{Bb}\end{array}$ & $\begin{array}{l}1.420 \pm \\
0.58 \mathrm{~b}\end{array}$ & $\begin{array}{l}0.500 \pm \\
0.06 \mathrm{a}\end{array}$ & $\begin{array}{l}1.920 \pm \\
0.62 \mathrm{Bb}\end{array}$ & $0.407 \pm 0.31 \mathrm{a}$ & $0.223 \pm 0.39 \mathrm{a}$ & $0.630 \pm 0.40 \mathrm{a}$ \\
\hline \multicolumn{2}{|l|}{ Forest types } & ns & $*$ & $* *$ & $* *$ & ns & $* *$ & $*$ & $*$ & $* *$ & $*$ & ns & $*$ \\
\hline
\end{tabular}

Table 4. C stored in the woody debris classified by the various diameter class in Acacia and Eucalyptus plantations of different stand age $\left(\mathrm{t} \cdot \mathrm{ha}^{-1}\right)$. Note: Values are shown as mean $\pm \mathrm{SD}$; different lower case $(P<0.05)$ and upper case $(P<0.01)$ letters within a column indicate a significant difference between the various ages of a given forest type; ns: not significant, *significant difference $(P<0.05)$, **extremely significant difference $(P<0.01)$ between the Eucalyptus and Acacia plantations.

$\mathrm{t} \cdot \mathrm{ha}^{-1}$ in the middle-aged and mature Eucalyptus plantations and 1.52 and $3.06 \mathrm{t} \cdot \mathrm{ha}^{-1}$ in the middle-aged and mature Acacia plantations. There was no statistical difference between the contributions made to the $\mathrm{C}$ stock by material of diameter $>30 \mathrm{~cm}$, irrespective of stand age. 


\begin{tabular}{|l|l|l|l|l|l|}
\hline \multirow{2}{*}{ Item } & Primary & Intermediate & Advanced \\
\cline { 2 - 5 } & I & II & III & V \\
\hline Bark & Present & Disappear & Disappear & Disappear \\
\hline Branch & Intact, tight & $\begin{array}{l}\text { Intact on the whole, tight } \\
\text { Branches keep intact }\end{array}$ & $\begin{array}{l}\text { Partly present, loose } \\
\text { present, Branches keep intact }\end{array}$ & $\begin{array}{l}\text { Absent of twigs, Branches } \\
\text { present, but mostly broken }\end{array}$ & $\begin{array}{l}\text { Absent of twigs, } \\
\text { Branches partly present }\end{array}$ \\
\hline $\begin{array}{l}\text { Wood consistency } \\
\text { and color }\end{array}$ & Solid, original color & Solid, original color & Semi-solid, faded & Party solid, breakable & Soft, powdery \\
\hline Moss or fungi & Disappear & $\begin{array}{l}\text { Cover less than } 25 \% \text { of } \\
\text { surface area }\end{array}$ & $\begin{array}{l}\text { Cover 25\% 50\% of surface } \\
\text { area }\end{array}$ & $\begin{array}{l}\text { Cover more than } 50 \% \\
\text { of surface area }\end{array}$ & $\begin{array}{l}\text { Cover more than } \\
50 \% \text { of surface area }\end{array}$ \\
\hline Root invading & Disappear & Disappear & Disappear & In sapwood \\
\hline
\end{tabular}

Table 5. Characteristics of woody debris at different decay classes in the forest ecosystem. Note: Data is from Tang and Zhou $^{30}$.

Both plantation type and stand age exerted a strong influence over the quantity of $\mathrm{C}$ present in the various woody debris decay state classes (Tables 5 and 6): there was a significantly different representation of the primary (I and II) and intermediate (III and IV) classes both between the two plantation types and between the three stand ages. Most of the woody debris was present in decay class I. Overall, the primary decay stage in both plantation types contributed most strongly, especially in the Eucalyptus plantations. Thus, in the middle-aged and mature plantations, the mean contribution to the $\mathrm{C}$ stored in the woody debris from material at the primary stage of decay was, $93 \%\left(0.54 \mathrm{t} \cdot \mathrm{ha}^{-1}\right)$ and $69 \%\left(0.83 \mathrm{t} \cdot \mathrm{ha}^{-1}\right)$ for Eucalyptus plantations, and $76 \%\left(3.48 \mathrm{t} \cdot \mathrm{ha} \mathrm{a}^{-1}\right)$ and $57 \%$ (3.80 th $\mathrm{ha}^{-1}$ ) for Acacia plantations, respectively. By contrast, material at the intermediate stage of decay contributed rather little: class IV material stored between $1 \%$ and $8 \%$ of the $\mathrm{C}$ stock. Notably, the woody debris in primary decay classes mainly presented in the form of logs and snags in both Eucalyptus and Acacia plantations.

Total ecosystem biomass and its $\mathbf{C}$ stock. The total ecosystem biomass in the two plantations increased sharply with stand age (Table 4). The present data revealed that the ecosystem $\mathrm{C}$ stock for the three age classes of Eucalyptus plantations was estimated as $29.75,75.66$ and $103.16 \mathrm{tha}^{-1}$, respectively, while the corresponding estimates for the three age classes of Acacia plantations were 43.84, 70.53 and $94.47 \mathrm{tha}^{-1}$.

\section{Discussion}

C concentration of the litter layer and the woody debris. The present findings demonstrate that the relative $\mathrm{C}$ concentration of both the litter layer and the woody debris in Eucalyptus and Acacia plantations was species-dependent, partially supporting our first hypothesis. In the present study, a fixed C concentration or mean value, rather than a measured $C$ concentration, would have been inappropriate for calculating the $C$ stock of litter layer and the woody debris for Eucalyptus plantations, leading to large estimated error of 12 and 9\%, respectively. However, the assumed concentration would have been more accurate for Acacia plantations (5\% estimated error in the $\mathrm{C}$ stock in both studied materials). The implication of this finding is that, in order to accurately estimate the size of the $\mathrm{C}$ stock, plantation type-specific measurements are necessary. It has been suggested that the $\mathrm{C}$ concentration in the woody debris on the floor of a humid evergreen broad-leaved plantation (49.0\%) is very similar to that estimated for the canopy as a whole $(50.4 \%)^{24}$, consistent with our finding in Acacia plantations. A recent study has shown that forest structure, in particular trunk diameter, may influence the $\mathrm{C}$ concentration of woody debris $^{22}$. It is likely that the high mortality rate suffered by Acacia trees gives other living trees more opportunity to absorb both sunlight and soil nutrient, thereby - at least to some extent - explaining the higher DBH values associated with their arbor layer (Table 1). The observed increase of DBH values implies a rise in the relative contribution of tree trunk wood to the total biomass, which is of relevance given that the trunks' $\mathrm{C}$ concentration tends to be higher than that of other parts of the biomass. As a result, the $\mathrm{C}$ concentration of the woody debris in Acacia plantations was found to be higher than in the Eucalyptus plantations.

The $\mathrm{C}$ concentration in the litter layer and woody debris depends on a number of factors, including forest type, stand condition and local climate $6,7,21,24,32-34$. The estimated $C$ concentration of the litter layer in the two types of plantations examined in the present study was comparable with values obtained from the broad-leaved plantations of subtropical China ${ }^{35}$, and local evergreen broad-leaved forests in the PRD region ${ }^{7,24}$. Possibly because the two species stem from the tropical zone, the estimated $\mathrm{C}$ concentration of woody debris in the two plantations fell within the range recorded for tropical species ${ }^{25}$. While the estimated $\mathrm{C}$ concentration of the woody debris of the Acacia plantations was somewhat higher than what has been reported for a tropical mixed Metrosideros polymorpha/Acacia plantations ${ }^{33}$, but was comparable with the value obtained from a range of coniferous and broad-leaved forests in temperate climates ${ }^{21,34}$, as well as from evergreen broad-leaved forests in the PRD region $^{7,36}$.

C stock of the litter layer. The $\mathrm{C}$ stock of the litter layer in the two plantations types, particularly the Acacia, was compared to estimates derived from the evergreen broad-leaved forests at a nationwide survey ${ }^{37}$, and the broadleaved tree forests in subtropical and mid-subtropical zone $e^{5,38}$, specific data see Table 7. The litter layer appears to serve an important role in $\mathrm{C}$ accumulation in plantations ecosystem, in particular for Acacia plantations. The size of the $\mathrm{C}$ stock contained in the litter layer was significantly higher in the Acacia than that in Eucalyptus plantations, especially in the leaf debris, which was the largest contributor to the litter layer C stock. Its relative contribution to the litter layer reached $72.6 \%$ in the Acacia plantations, in agreement with both global 


\begin{tabular}{|c|c|c|c|c|c|c|c|c|c|c|c|c|c|}
\hline \multirow[b]{3}{*}{ Item } & & \multicolumn{6}{|l|}{ Primary } & \multicolumn{6}{|c|}{ Intermediate } \\
\hline & & \multicolumn{3}{|l|}{ I } & \multicolumn{3}{|l|}{ II } & \multicolumn{3}{|c|}{ III } & \multicolumn{3}{|l|}{ IV } \\
\hline & & Snags & logs & $\begin{array}{l}\text { woody } \\
\text { debris }\end{array}$ & Snags & logs & $\begin{array}{l}\text { woody } \\
\text { debris }\end{array}$ & Snags & logs & woody debris & Snags & logs & woody debris \\
\hline \multirow{3}{*}{ Eucalyptus } & Young & $0 \mathrm{Aa}$ & 0Aa & 0Aa & $0 \mathrm{a}$ & 0Aa & $0 \mathrm{~A}$ & $0 \mathrm{a}$ & 0Aa & 0Aa & $0 \mathrm{a}$ & $0 \mathrm{a}$ & $0 \mathrm{a}$ \\
\hline & \begin{tabular}{|l}
$\begin{array}{l}\text { Middle- } \\
\text { aged }\end{array}$ \\
\end{tabular} & $\begin{array}{l}0.199 \pm \\
0.10 \mathrm{Bb}\end{array}$ & $\begin{array}{l}0.064 \pm \\
0.05 \mathrm{AB}\end{array}$ & $\begin{array}{l}0.263 \pm \\
0.10 \mathrm{Bb}\end{array}$ & $\begin{array}{l}0.177 \pm \\
0.09 \mathrm{~b}\end{array}$ & $\begin{array}{l}0.100 \pm \\
0.08 \mathrm{Aa}\end{array}$ & \begin{tabular}{|l|}
$0.277 \pm$ \\
$0.89 \mathrm{~B}$ \\
\end{tabular} & $\begin{array}{l}0.024 \pm \\
0.03 \mathrm{ab} \\
\end{array}$ & $\begin{array}{l}0.016 \pm \\
0.03 \mathrm{Aa}\end{array}$ & $0.040 \pm 0.05 \mathrm{Aa}$ & 0a & 0a & $0 \mathrm{a}$ \\
\hline & Mature & $\begin{array}{l}0.142 \pm \\
0.10 \mathrm{Aa}\end{array}$ & $\begin{array}{l}0.195 \pm \\
0.05 \mathrm{Bc}\end{array}$ & $\begin{array}{l}0.337 \pm \\
0.14 \mathrm{Bb}\end{array}$ & $\begin{array}{l}0.191 \pm \\
0.13 \mathrm{~b}\end{array}$ & $\begin{array}{l}0.301 \pm \\
0.08 \mathrm{Bb}\end{array}$ & $\begin{array}{l}0.491 \pm \\
0.04 \mathrm{C}\end{array}$ & $\begin{array}{l}0.124 \pm \\
0.13 \mathrm{~b}\end{array}$ & $\begin{array}{l}0.227 \pm \\
0.07 \mathrm{Bb}\end{array}$ & $0.351 \pm 0.09 \mathrm{Bb}$ & 0a & $0.028 \pm 0.05 \mathrm{a}$ & $0.028 \pm 0.05 \mathrm{a}$ \\
\hline \multirow{3}{*}{ Acacia } & Young & $\begin{array}{l}0.057 \pm \\
0.03 \mathrm{Aa} \\
\end{array}$ & $\begin{array}{l}0.124 \pm \\
0.01 \mathrm{a} \\
\end{array}$ & $\begin{array}{l}0.181 \pm \\
0.04 \mathrm{Aa} \\
\end{array}$ & $\begin{array}{l}0.043 \pm \\
0.02 \mathrm{Aa}\end{array}$ & $\begin{array}{l}0.206 \pm \\
0.09 \mathrm{a} \\
\end{array}$ & $\begin{array}{l}0.249 \pm \\
0.10 \mathrm{a} \\
\end{array}$ & $0 \mathrm{a}$ & $0 \mathrm{a}$ & 0Aa & 0a & 0a & 0a \\
\hline & $\begin{array}{l}\text { Middle- } \\
\text { aged }\end{array}$ & $\begin{array}{l}1.207 \pm \\
0.56 \mathrm{Bb}\end{array}$ & $\begin{array}{l}0.693 \pm \\
0.49 a \\
\end{array}$ & $\begin{array}{l}1.901 \pm \\
0.65 \mathrm{Bb}\end{array}$ & $\begin{array}{l}1.032 \pm \\
0.43 \mathrm{ab} \\
\end{array}$ & $\begin{array}{l}0.542 \pm \\
0.42 \mathrm{a} \\
\end{array}$ & $\begin{array}{l}1.575 \pm \\
0.45 \mathrm{ab}\end{array}$ & $\begin{array}{l}0.523 \pm \\
0.74 \mathrm{a}\end{array}$ & $\begin{array}{l}0.523 \pm \\
0.58 \mathrm{ab}\end{array}$ & $1.046 \pm 0.87 \mathrm{ABa}$ & 0a & $0.039 \pm 0.08 \mathrm{a}$ & $0.039 \pm 0.08 \mathrm{a}$ \\
\hline & Mature & $\begin{array}{l}1.01 \pm \\
0.37 \mathrm{ABb}\end{array}$ & $\begin{array}{l}0.346 \pm \\
0.30 \mathrm{a}\end{array}$ & $\begin{array}{l}1.358 \pm \\
0.65 \mathrm{ABb}\end{array}$ & $\begin{array}{l}2.084 \pm \\
1.11 \mathrm{Bb}\end{array}$ & $\begin{array}{l}0.354 \pm \\
0.37 \mathrm{a}\end{array}$ & $\begin{array}{l}2.44 \pm \\
1.48 \mathrm{~b}\end{array}$ & $\begin{array}{l}0.803 \pm \\
0.40 \mathrm{a}\end{array}$ & $\begin{array}{l}1.500 \pm \\
1.14 \mathrm{~b}\end{array}$ & $2.303 \pm 0.74 \mathrm{Bb}$ & $\begin{array}{l}0.047 \pm \\
0.08 \mathrm{a}\end{array}$ & $0.533 \pm 0.50 \mathrm{~b}$ & $0.580 \pm 0.57 \mathrm{a}$ \\
\hline \multicolumn{2}{|l|}{ Forest types } & $* *$ & $*$ & $* *$ & $* *$ & $*$ & ** & $*$ & $*$ & *** & ns & ns & ns \\
\hline
\end{tabular}

Table 6. The $\mathrm{C}$ stock in woody debris across various decay classes and plantation ages ( $\left.\mathrm{t} \cdot \mathrm{ha} \mathrm{a}^{-1}\right)$. Note: Values shown as mean $\pm \mathrm{SD}$; different lower case $(P<0.05)$ and upper case $(P<0.01)$ letters within a column indicate a significant difference between the various ages of a given plantation type; ns: not significant, *: significant difference $(P<0.05)$, **: extremely significant difference $(P<0.01)$ between the Eucalyptus and Acacia plantations.

\begin{tabular}{|c|c|c|c|c|}
\hline Item & Forest Type & $\begin{array}{l}\text { Stand } \\
\text { age (a) }\end{array}$ & $\begin{array}{l}\text { Mean Value } \\
\text { (Standard Error) }\end{array}$ & References and description \\
\hline \multirow{3}{*}{$\begin{array}{l}\text { Forest floor } \\
\text { litter }\end{array}$} & Liquidamba formosana & 19 & $1.88(0.28)$ & \multirow{3}{*}{$\begin{array}{l}\text { References }{ }^{5} \text {, subtropical } \\
\text { plantations, a total of } 18 \text { plots. }\end{array}$} \\
\hline & Schima superb & 19 & $3.74(0.23)$ & \\
\hline & Pinus massoniana & 19 & $4.57(0.15)$ & \\
\hline \multirow[b]{2}{*}{ Litter layer } & $\begin{array}{l}\text { evergreen broad-leaved forests } \\
\text { at national level }\end{array}$ & - & 3.21 & $\begin{array}{l}\text { References }^{37}, 250 \text { sets of data } \\
\text { from the reference }\end{array}$ \\
\hline & evergreen broad-leaved forests & - & $4.25 \sim 5.57$ & $\begin{array}{l}\text { References }^{38} 52 \text { stands from } \\
\text { young to mature forests in } \\
\text { mid-subtropical zone. }\end{array}$ \\
\hline
\end{tabular}

Table 7. The $\mathrm{C}$ stock of the litter layer from the other types of broad-leaved forests $\left(\mathrm{t} \cdot \mathrm{ha}^{-1}\right)$. Note: - indicates data unavailable or no data.

estimates (60-76\%) and its contribution in tropical Eucalyptus forests $(79 \%)^{32}$. In contrast, its contribution in the Eucalyptus plantations examined in the present study was only $54.3 \%$. The quantity of leaf litter has been reported to be associated with the annual increment in the $\mathrm{DBH}^{39}$. Here, particularly in the Acacia plantations, the DBH increased significantly with stand age, implying that the contribution of leaf litter to the $\mathrm{C}$ stock would increase accordingly.

Characteristics of the woody debris C stock. C stock of woody debris and its distribution in snags and logs. The measured C stock of the woody debris in the two forest types was significantly lower than that reported for both tropical montane wet forests and moist evergreen broad-leaved forests ${ }^{33,35}$. A comparison among evergreen broad-leaved forests in the PRD region revealed that the $\mathrm{C}$ stock of woody debris in the Acacia plantations was similar to that in forests composed of middle-aged and mature trees reported by Sun and Guan ${ }^{8}$, but significantly lower than that measured in mature forests by Yang et al. ${ }^{2}$ It is possible that the high growth rate of Acacia does not allow insufficient time for the woody debris to accumulate; the size of the $\mathrm{C}$ stock of woody debris in the mature Acacia plantations was significantly higher than in the mature Eucalyptus ones (6.68 vs $\left.1.21 \mathrm{t} \mathrm{ha}^{-1}\right)$, levels comparable to those seen in other subtropical plantations $s^{5,40}$ (Table 8).

Our study showed that forests type and stand age affect the amount of $\mathrm{C}$ stored in woody debris and its distribution in snags and logs. Snags represented the principal component of the woody debris, contributing $60.5 \%$ in the middle-aged Acacia plantations and 59.0\% in the mature ones. These proportions differ markedly from the composition in tropical and subtropical broad-leaved forests, where logs account for 59-95\% of the woody debris $^{2,5,8,40}$. It has been suggested that most of the woody debris production (especially snags) is generated as a results of competition between adjacent trees, the death of old trees and external factors, such as weather events, pest and disease damage, and logging ${ }^{4,33}$. A large amount of snags present in Acacia plantations may be explained by the high mortality rate of standing trees, in line with conclusions drawn from similar studies ${ }^{17}$. With the exception of the mature Acacia plantations, the mortality rate of canopy in our study falls within the range of that for subtropical forests in the PRD region (1.7-12.3\% per annual) ${ }^{41}$. The size of the C stock in the logs of the Acacia plantations was greater than that for Eucalyptus. It is likely that many of these logs were the result of wind-induced breakage; therefore, their frequency is expected to be higher in the Acacia than in the Eucalyptus plantations. 


\begin{tabular}{|c|c|c|c|c|}
\hline Item (Diameter) & Forest Type & $\begin{array}{l}\text { The given year } \\
\text { (stand age) }\end{array}$ & $\begin{array}{l}\text { Mean Value } \\
\text { (Standard Error) }\end{array}$ & References \\
\hline \multirow{4}{*}{$\begin{array}{l}\text { Wood debris } \\
>5 \mathrm{~cm}\end{array}$} & Liquidamba formosana & 19 & $7.1(0.39)$ & \multirow{4}{*}{5,40} \\
\hline & Schima superb & 19 & $0.34(0.06)$ & \\
\hline & Pinus massoniana & 19 & $0.45(0.04)$ & \\
\hline & P. elliottii & 19 & $0.33(0.15)$ & \\
\hline \multirow{3}{*}{$\begin{array}{l}\text { woody debris } \\
(>=10 \mathrm{~cm})\end{array}$} & Young forests & $<40$ & $2.86(0.48)$ & \multirow{3}{*}{8} \\
\hline & Middle-aged forests & $60-100$ & $5.75(1.65)$ & \\
\hline & Mature forests & $>150$ & $11.37(0.20)$ & \\
\hline \multirow{5}{*}{$\begin{array}{l}\text { woody debris } \\
(>=10 \mathrm{~cm})\end{array}$} & \multirow{5}{*}{$\begin{array}{l}\text { Old evergreen broad-leaved } \\
\text { forests }\end{array}$} & 1992 & 7.64 & \multirow{5}{*}{2} \\
\hline & & 1994 & 9.56 & \\
\hline & & 1999 & 11.09 & \\
\hline & & 2004 & 11.36 & \\
\hline & & 2008 & 19.66 & \\
\hline $\begin{array}{l}\text { woody debris } \\
(>=2 \mathrm{~cm})\end{array}$ & $\begin{array}{l}\text { Mixed Metrosideros polymorpha } \\
\text { Acacia koa forests }\end{array}$ & 2009 & 44.3 & 33 \\
\hline $\begin{array}{l}\text { woody debris } \\
(>=10 \mathrm{~cm})\end{array}$ & Primary forests & 2007 & 31.61 & 35 \\
\hline
\end{tabular}

Table 8. The $\mathrm{C}$ stock in the woody debris from other types of broad-leaved forests $\left(\mathrm{t} \cdot \mathrm{ha} \mathrm{a}^{-1}\right)$. Note: The given year represents the estimated year.

\begin{tabular}{|c|c|c|c|c|}
\hline \multirow[b]{2}{*}{ Ages periods } & \multicolumn{2}{|c|}{ woody debris/ Litter (mean value (SE)) } & \multirow{2}{*}{$\begin{array}{l}\text { Ecosystem C } \\
\text { stock }\end{array}$} & \multirow[b]{2}{*}{ Description } \\
\hline & Litter & woody debris & & \\
\hline Young forests & $2.12(0.26)$ & $2.86(0.48)$ & 5.11 & \multirow{3}{*}{$\begin{array}{l}\text { Reference }^{8}, \text { ecosystem biomass C, } \\
\text { author's calculation }\end{array}$} \\
\hline Middle-aged forests & $2.45(0.30)$ & $5.75(1.65)$ & 116.62 & \\
\hline Mature forests & $2.64(0.31)$ & $11.37(0.20)$ & 176.23 & \\
\hline Young forests & 2.13 & 1.92 & 31.96 & \multirow{3}{*}{40} \\
\hline Middle-aged forests & 3.16 & 5.52 & 95.23 & \\
\hline Mature forests & 4.37 & 8.78 & 194.28 & \\
\hline
\end{tabular}

Table 9. The $\mathrm{C}$ stock of the woody debris and litter layer in subtropical broad-leaved forests ( $\left.\mathrm{t} \cdot \mathrm{ha}^{-1}\right)$. Note:This was the basic data used for the calculation of the proportional contribution to the ecosystem $\mathrm{C}$ stock of the woody debris and the litter layer in subtropical evergreen broad-leaved forests. SE: standard error of the mean; ecosystem biomass $\mathrm{C}$ stock: the sum of $\mathrm{C}$ stored in the arbor layer, shrub, herb, litter layer and woody debris; diameter of woody debris: $\geq 10 \mathrm{~cm}$.

C stock in various diameter class of woody debris. Fallen wood of smaller diameter experiences a greater degree of contact with the ground, and therefore tends to decompose faster ${ }^{42}$. Woody debris material of Small diameter was more frequent in the Acacia plantations than in the Eucalyptus ones, verifying the hypothesis that forest type affects the $\mathrm{C}$ stock within the woody debris of a specific diameter class. The difference between the two plantations types is most likely due to the contrasting wind resistance, particularly for A. mangium and E. urophylla. The PRD region is the area in China where typhoons occur most frequently, and two strong typhoons were recorded here in 2010 alone. Consequently, the proportion of the $C$ stock within woody debris of small diameter $(2.5-10 \mathrm{~cm})$ in the Acacia plantations was larger than the range of $40-75 \%$ reported in secondary subtropical broad-leaved forests of comparable age ${ }^{36}$, as well as that in forests within the United States $(28 \%)^{43}$. The C stock proportion in both the mature Eucalyptus and Acacia plantations (17 and 16\%, respectively) was markedly higher than the $~ 6 \%$ reported in primary moist evergreen broad-leaved tropical forests ${ }^{35}$. The $\mathrm{C}$ stock contained in the debris of diameter class $10-20 \mathrm{~cm}$ represented the largest contributor to the total C stock of woody debris in the middle-age Eucalyptus and mature Acacia plantations, possibly partially due to the majority of standing trees having a mean DBH of $10-20 \mathrm{~cm}$. This finding further supports the hypothesis that stand age affects the $\mathrm{C}$ stock within the woody debris of a particular diameter range.

Carbon stock at the stage of various decay class of woody debris. In subtropical natural forests, an estimated $50 \sim 90 \%$ of the woody debris is in an intermediate-to-advanced state of decay ${ }^{2,3}$; a significantly higher proportion than that observed in the present study. This discrepancy is possibly due to the rapid growth rate of both Eucalyptus and Acacia trees limiting the time available for woody debris to decay to an advanced degree. Between the two species studies here, the share of the $\mathrm{C}$ stock in the woody debris (largely at an early stage of decay) was higher in the Eucalyptus than in the Acacia plantations. The outcome of the present study verifies the hypothesis that forest type exerts a significant influence on the $\mathrm{C}$ stock in the woody debris at particular stages of decay. Even in the mature forests, the $\mathrm{C}$ stock contained by material at an early decay stage made a significant contribution to 

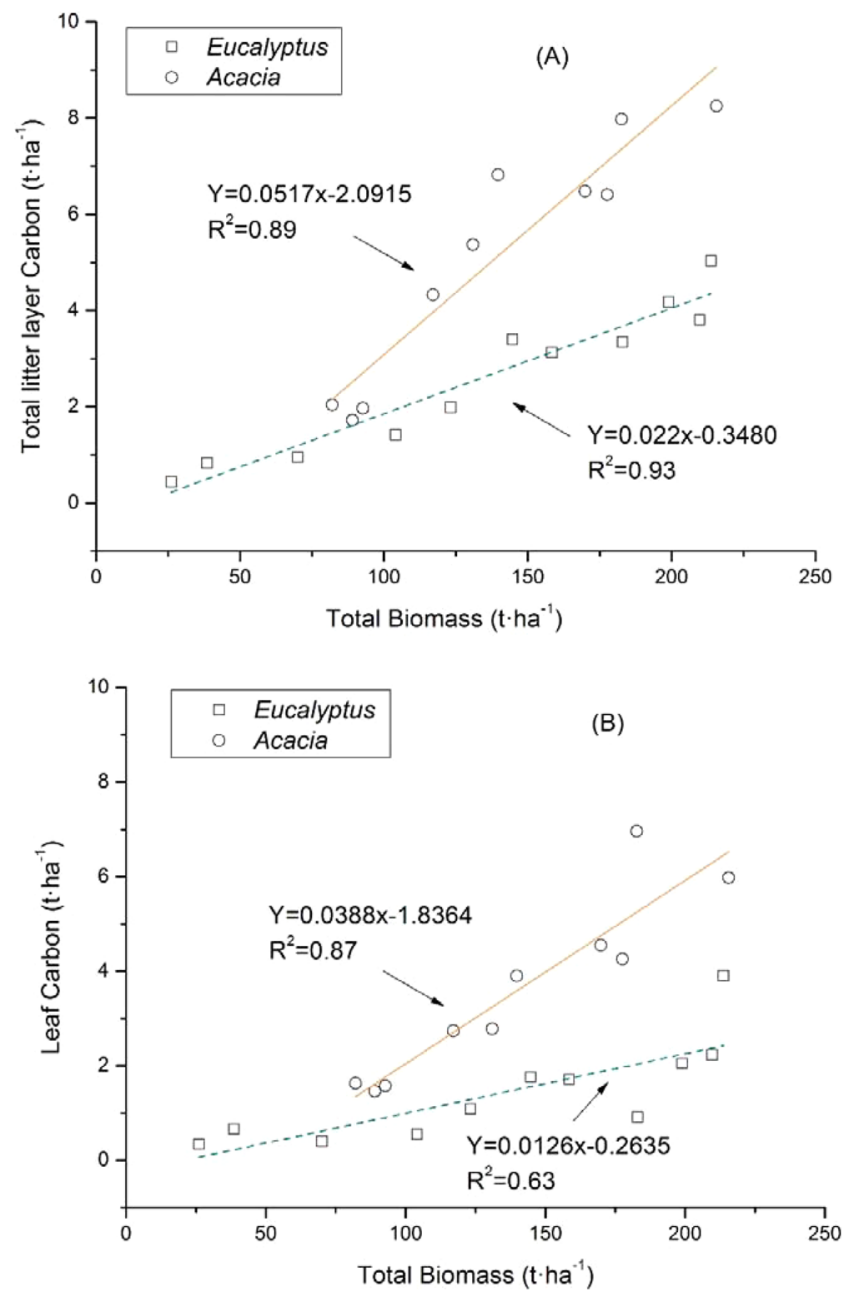

Figure 1. The relationship between the total biomass and the $\mathrm{C}$ stock in the litter layer (and its various components) in Eucalyptus and Acacia plantations.

the overall C stock of woody debris. The extent of this contribution was substantially greater than that reported for primary forests $(\sim 20 \%)$, but markedly lower than that associated with mature evergreen broad-leaved forests and mixed old Metrosideros polymorpha/Acacia koa forests (64 and 66\%, respectively) $)^{2,33}$.

In the forest ecosystem, most of the woody debris in the primary decay stage has been created by dead trees and wind damage ${ }^{3,10}$. The snags classed in primary decay in the Acacia plantations are likely the result of a combination of typhoons and high mortality rate. A high percentage of woody debris in the plantations of the present study was allocated in decay class I, representing the effect of typhoons. In the Eucalyptus plantations, logs were the principal source of woody debris in a primary decay stage, in agreement with conclusions derived from analyses of secondary forests ${ }^{3}$.

The contribution of the litter layer and woody debris to the ecosystem's C stock. In terms of the respective contribution of $\mathrm{C}$ stock by the litter layer and woody debris to the forest ecosystem, the values determined for the Acacia plantations (6.8 and 5.0\%, respectively) were significantly higher than those for the Eucalyptus plantations (3.7 and $0.7 \%$, respectively). Even in mature Acacia plantations the value reached 8.0 and $7.1 \%$, compared with a mere 4.2 and $1.2 \%$, respectively, for mature Eucalyptus. These findings indicate that both forest type and stand age impact on the capacity of the litter layer and woody debris to store C, in support of our third hypothesis. The contribution of the litter layer in Acacia plantations was higher than that previously reported for subtropical evergreen broad-leaved forests in the PRD region (1.5-6.7\%; Table 9), as well as than the estimated worldwide mean of $5 \%{ }^{44}$. With respect to the contribution of the woody debris, the value for the Acacia plantations was greater than the estimated Guangdong province-wide mean of $3 \%{ }^{9}$, but comparable to estimates from local evergreen broad-leaved forests (4.9-6.5\%; Table 9). Therefore, both the litter layer and woody debris appear to contribute significantly to long-term C storage, particularly in Acacia plantations.

Relationship between total biomass and C stock of litter layer and woody debris. The combination of the biomass quantity and the $\mathrm{C}$ concentration within it determines the overall size of the $\mathrm{C}$ stock present in a given component. A positive correlation was obtained between the total biomass of both the litter layer and 

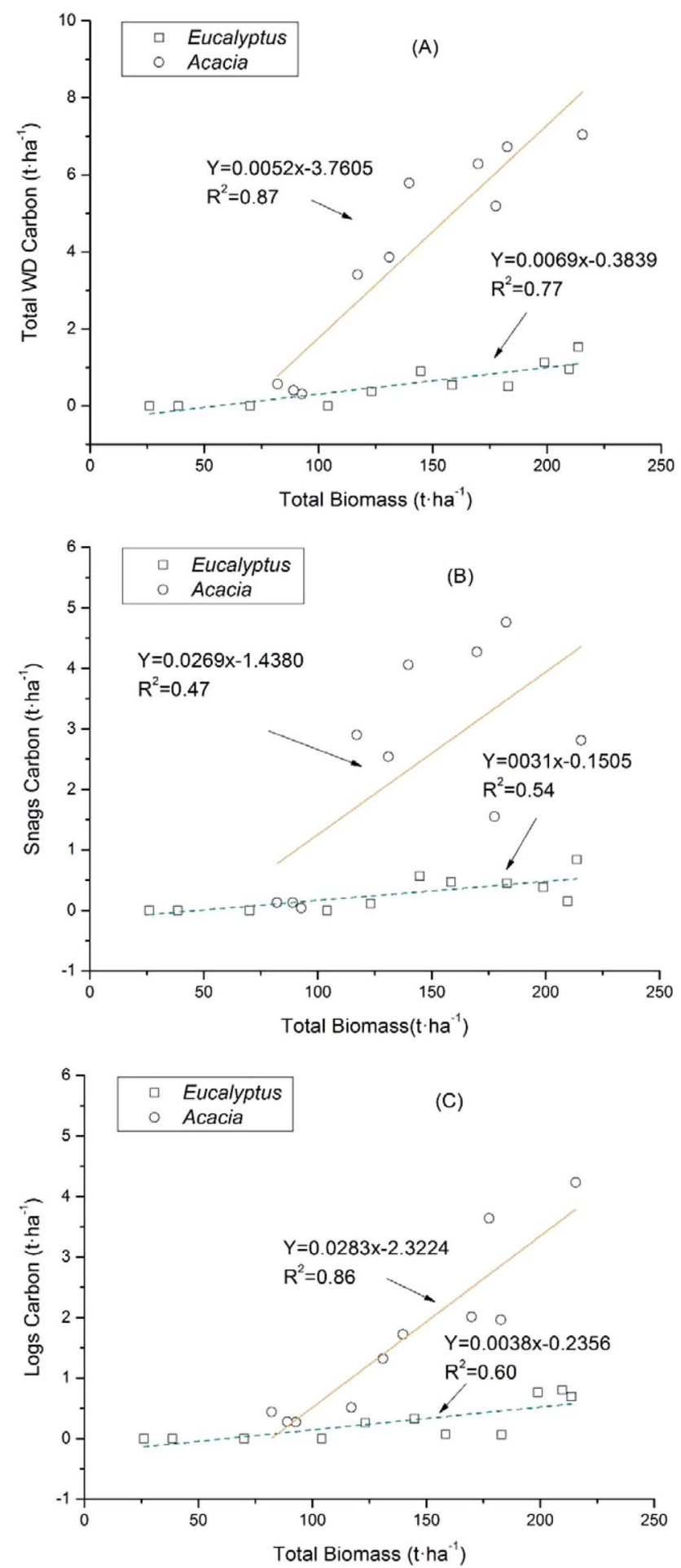

Figure 2. The relationship between the total biomass and the $\mathrm{C}$ stock in the woody debris (and its various components) in Eucalyptus and Acacia plantations.

the woody debris and their respective components (Figs. 1 and 2), with the highest coefficients of determination corresponding to the total litter layer ( 0.89 and 0.93 for Acacia and Eucalyptus, respectively; Fig. 1A) and the total woody debris (0.87 and 0.77 for Acacia and Eucalyptus, respectively; Fig. 2A). The implication of this finding is that the $\mathrm{C}$ stock of the litter layer and woody debris may be restricted by the ecosystem biomass to a great extent. The conclusion is consistent with a study in which the $\mathrm{C}$ stock in the litter layer and the woody debris under evergreen broad-leaved trees in southern China was reported to lie in the ranges 2.13-4.37 and 1.92-8.78 t.ha ${ }^{-1}$, respectively, in line with the variation found in the ecosystem biomass $\left(66.3-391.9 \mathrm{t} \cdot \mathrm{ha} \mathrm{a}^{-1}\right)^{7}$. 


\section{Conclusion}

The present study describes the characteristics of the $\mathrm{C}$ stock in the litter layer and woody debris of Eucalyptus and Acacia plantations of different ages. Acacia trees exhibited a better ability than Eucalyptus trees to store C in their litter layer and woody debris; this was especially the case for slags of diameter $10-20 \mathrm{~cm}$ in the primary decay stage, which arose from a combination of the natural mortality (especially in the more mature plantations) and natural disturbances such as strong wind. The indications are that forest type as well as stand age are important determinants of the accumulation and distribution of the $\mathrm{C}$ stock of both the litter layer and the woody debris. Forest type was also a key driver of the $\mathrm{C}$ concentration in both the litter layer and the woody debris, a finding that could improve the accuracy of $\mathrm{C}$ stock determination. In order to maximize the $\mathrm{C}$-sequestration potential of the litter layers and woody debris, future plantation management should focus on the tree species selected for reforestation, in particular for $\mathrm{N}_{2}$-fixing trees species such as Acacia, and on the C-sequestration ability of mature plantations.

Received: 25 September 2019; Accepted: 26 February 2020;

Published online: 13 March 2020

\section{References}

1. Russell, M. B. et al. Quantifying carbon stores and decomposition in dead wood: A review. For. Ecol. Manag. 350, 107-128 (2015).

2. Yang, F. F. et al. Dynamics of coarse woody debris and decomposition rates in an old-growth forest in lower tropical China. For. Ecol. Manag. 259, 1666-1672 (2010).

3. Yuan, J. et al. Characteristics in coarse woody debris mediated by forest developmental stage and latest disturbances in a natural secondary forest of Pinus tabulaeformis. Acta Ecol. Sin. 34, 232-238 (2014).

4. Yan, E. R. et al. Long-lasting legacy of forest succession and forest management: Characteristics of coarse woody debris in an evergreen broad-leaved forest of Eastern China. For. Ecol. Manag. 252, 98-107 (2007).

5. Wei, X. et al. Restoring ecosystem carbon sequestration through afforestation: A sub-tropic restoration case study. For. Ecol. Manag. 300, 60-67 (2013).

6. Zhang, H. et al. Biomass and carbon storage in an age-sequence of Cyclobalanopsis glauca plantations in southwest China. Ecol. Eng. 73, 184-191 (2014).

7. Zhang, X. Allocation characteristics of three chiefforest biomass and carbon stock in Guangzhou Ph.D thesis, Sun Yat Sen University, China, (2009).

8. Sun, L. \& Guan, D. Carbon stock of the ecosystem of lower subtropical broadleaved evergreen forests of different ages in Pearl River Delta, China. J. Trop. For. Sci., 249-258 (2014).

9. Zhao, J. \& Haikui, L. I. Characteristics of the forest deadwood carbon pool in Guangdong Province. Acta Ecol. Sin. 38, 550-559 (2018).

10. Alberti, G. et al. Forest ecosystem carbon accumulation during a secondary succession in the Eastern Prealps of Italy. Forestry 81, 1-11 (2008).

11. China's State Forestry Administration. China Forest Resources Report: the 8th National Inventory of Forest Resources (2014).

12. Cao, J. et al. Leaf litter contributes more to soil organic carbon than fine roots in two 10-year-old subtropical plantations. Sci. Total Environ. 704, 135-341 (2020).

13. Santana, G. S., Knicker, H., González-Vila, F. J., González-Pérez, J. A. \& Dick, D. P. The impact of exotic forest plantations on the chemical composition of soil organic matter in Southern Brazil as assessed by Py-GC/MS and lipid extracts study. Geoderma Reg. 4, 11-19(2015).

14. Cook, R. L. et al. Eucalyptus plantation effects on soil carbon after 20years and three rotations in Brazil. For. Ecol. Manag. 359, 92-98 (2016).

15. Kasel, S. et al. T. Species-specific effects of native trees on soil organic carbon in biodiverse plantings across north-central Victoria, Australia. Geoderma 161, 95-106 (2011).

16. Attiwill, P. M. Ecological disturbance and the conservative management of Eucalypt forests in Australia. For. Ecol. Manag. 63, 301-346 (1994).

17. Inagaki, M. et al. Nutrient dynamics through fine litterfall in three plantations in Sabah, Malaysia, in relation to nutrient supply to surface soil. Nutr. Cycl. Agroecosys 88, 381-395 (2010).

18. Kasel, S. et al. Species-specific effects of native trees on soil organic carbon in biodiverse plantings across north-central Victoria, Australia. Geoderma 161, 0-106 (2011).

19. Pereira, A. P. A. et al. Mixed Eucalyptus plantations induce changes in microbial communities and increase biological functions in the soil and litter layers. For. Ecol. Manag. 433, 332-342 (2019).

20. Harmon, M. E. et al. Woody Detritus Density and Density Reduction Factors for Tree Species in the United States: A Synthesis. US. For. Serv., Gen. Tech. Rep. 29, Northern Research Station (2008).

21. Harmon, M. E. et al. Carbon concentration of standing and downed woody detritus: Effects of tree taxa, decay class, position, and tissue type. For. Ecol. Manag. 291, 259-267 (2013).

22. Chao, K. J. et al. Carbon concentration declines with decay class in tropical forest woody debris. For. Ecol. Manag. 391, 75-85 (2017).

23. Zheng, Z. et al. Effects of nutrient additions on litter decomposition regulated by phosphorus-induced changes in litter chemistry in a subtropical forest, China. For. Ecol. Manag. 400, 123-128 (2017).

24. Yang, K. Study on undergrowth of main forest types and regional forest biomass in the Pearl Revier Delta Ph.D. Thesis thesis, Sun Yat Sen University, China, (2007).

25. Thomas, S. C. \& Martin, A. R. Carbon content of tree tissues: a synthesis. Forests 3, 332-352 (2012).

26. Zhang, H. et al. Biomass and carbon storage of Eucalyptus and Acacia plantations in the Pearl River Delta, South China. For. Ecol. Manag. 277, 90-97 (2012).

27. Ye, S. M. et al. Biomass and productivity of stratified mixed stands of Eucalyptus urophylla and Acacia mangium. Journal of Beijing Forestry University 30, 37-42 (2008).

28. Ren, H. et al. Biomass and net primary productivity in an Acacia mangium plantation in Heshan, Guangdong, China. Acta Phytoecol. Sin. 24, 18-21 (2000).

29. Wei, P. et al. The biomass and characteristic of the dead trees in mosoon evergreen broad-leavede forest in dinghushan. Acta Ecol. Sin. 17, 505-510 (1997).

30. Tang, X. L. \& Zhou, G. Y. Coarse woody debris biomass and its potential contribution to the carbon cycle in successional subtropical forests of southern China. Acta Phytoecol. Sin. 29, 559-568 (2005).

31. IPCC. Good Practice Guidance for Land Use, Land Use Change and Forestry. Institute for Global Environmental Strategies. Intergovernmental panel on climate change (IPCC) (2003).

32. Cizungu, L. et al. Litterfall and leaf litter decomposition in a central African tropical mountain forest and Eucalyptus plantation. For. Ecol. Manag. 326, 109-116 (2014). 
33. Iwashita, D. K. et al. Coarse woody debris carbon storage across a mean annual temperature gradient in tropical montane wet forest. For. Ecol. Manag. 291, 336-343 (2013).

34. Köster, K. et al. Dead wood basic density, and the concentration of carbon and nitrogen for main tree species in managed hemiboreal forests. For. Ecol. Manag. 354, 35-42 (2015).

35. Yang, L. P. et al. Composition and carbon storage of woody debris in moist evergreen broad-leaved forest and its secondary forests in Ailao Mountains of Yunnan Provinve. Chin. J. Appl. Ecol. 18, 2153-2159 (2007).

36. Zhang, X. Y. \& Guan, D. S. Characteristics of storage and decomposition of coarse woody debris (CWD) under three forests in Guangzhou. Acta Ecol. Sin. 29, 5227-5236 (2009).

37. Zhou, Y. R. et al. Carbon storage and budget of major Chinese forest types. Chin J Plan Ecolo 24, 518-522 (2000).

38. Chen, L. C. et al. Spatiotemporal patterns of carbon storage in forest ecosystems in Hunan Province, China. For. Ecol. Manag. 432, 656-666 (2019).

39. Matala, J. et al. Litterfall in relation to volume growth of trees: analysis based on literature. Scand J For. Res. 23, 194-202 (2008).

40. He, Y. et al. Carbon storage capacity of monoculture and mixed-species plantations in subtropical China. For. Ecol. Manag. 295, 193-198 (2013).

41. Ma, L. et al. Forest dynamics and its driving forces of sub-tropical forest in South China. Sci. Rep. 6, 22561, https://doi.org/10.1038/ srep22561 (2016)

42. Wu, C. et al. Effects of Stand Origin and Near-Natural Restoration on the Stock and Structural Composition of Fallen Trees in MidSubtropical Forests. Forests 6, 4439-4450 (2015).

43. Woodall, C. W. et al. Biomass and carbon attributes of downed woody materials in forests of the United States. For. Ecol. Manag. 305, 48-59 (2013).

44. Domke, G. M. et al. Estimating litter carbon stocks on forest land in the United States. Sci. Total Environ. 557-558, 469-478 (2016).

\section{Acknowledgements}

We would like to thank the financial support from Fundamental Research Funds for the Central Universities (2662018JC056), the Ministry of Education Humanities and Social Sciences Research Projects (17YJC840013) and the Fundamental Research Funds in Wuhan Institute of Technology (19QD44). Experimental facilities were provided by Guangdong Provincial Key Laboratory of Environmental Pollution Control and Remediation Technology, the School of Environmental Science and Engineering, Sun Yat-sen University.

\section{Author contributions}

Hui Zhang wrote the full manuscript. Hui Zhang and Mingwei Song designed and conducted the experiment, as well as revised the manuscript. Jiajun He analyzed the experimental data, and provided some helpful suggestions on the manuscript during the course of editing and revising the manuscript together with Yinhua Jiang. Dongsheng Guan provided some good suggestions during the course of the experiment and data processing.

\section{Competing interests}

The authors declare no competing interests.

\section{Additional information}

Correspondence and requests for materials should be addressed to M.S. or J.H.

Reprints and permissions information is available at www.nature.com/reprints.

Publisher's note Springer Nature remains neutral with regard to jurisdictional claims in published maps and institutional affiliations.

(c) (i) Open Access This article is licensed under a Creative Commons Attribution 4.0 International License, which permits use, sharing, adaptation, distribution and reproduction in any medium or format, as long as you give appropriate credit to the original author(s) and the source, provide a link to the Creative Commons license, and indicate if changes were made. The images or other third party material in this article are included in the article's Creative Commons license, unless indicated otherwise in a credit line to the material. If material is not included in the article's Creative Commons license and your intended use is not permitted by statutory regulation or exceeds the permitted use, you will need to obtain permission directly from the copyright holder. To view a copy of this license, visit http://creativecommons.org/licenses/by/4.0/.

(C) The Author(s) 2020 